DE DE GRUYTER OPEN

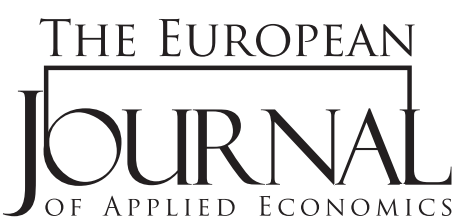

EJAE 2017, 14(1): 13-23

ISSN 2406-2588

UDK: 658.153.1.1(497.11)"2008/2013"

DOI: $10.5937 /$ ejae14-13574

Original paper/Originalni naučni rad

\title{
ANALYSIS OF THE DETERMINANTS OF CORPORATE CASH HOLDINGS: EXAMPLES FROM COMPANIES IN SERBIA
}

\author{
Željko Račić ${ }^{1 *}$, Nemanja Stanišić ${ }^{2}$ \\ ${ }^{1}$ Higher School of Professional Business Studies, \\ 4 Vladimira Perića Valtera Street, Novi Sad, Serbia \\ ${ }^{2}$ Singidunum University, \\ 32 Danijelova Street, Belgrade, Serbia
}

\begin{abstract}
:
In this study, we aimed to analyse the empirical determinants of cash holdings on the sample of non-financial companies operating in the Republic of Serbia. For that purpose, dynamic panel data models were estimated by utilising the generalised method of moments for the period from 2008 to 2013. The econometric analysis indicates that companies with higher cash flow hold more cash in their assets. Larger companies as well as companies with more liquid assets and higher turnover coefficients tend to reduce their cash levels. According to the results, companies operating in the Republic of Serbia tend to hold the optimal level of cash and prefer internal sources of financing, which is in line with the principles of trade-off theory and pecking order theory.
\end{abstract}

\section{Key words:}

liquidity, sources of financing, corporate cash holding, Republic of Serbia, dynamic panel models.

\section{INTRODUCTION}

Despite the fact that cash is the least productive asset, companies have to maintain certain amounts of cash and cash equivalents. There are several relevant concepts explaining what motivates managers to maintain cash holdings at certain levels. The differences between these concepts originate in differences between various attitudes towards the benefits and costs of cash holding (Opler, Pinkowitz \& Williamson, 1999).

^E-mail: raciczeljko@gmail.com
According to Keynes (1936), motives for holding cash may be transactional, precautionary, or speculative. Transactional motives originate from the point that companies cover their own transaction costs from their own funds. Speculative motives relate to the ability to finance profitable investment activities from cash reserves in order to avoid the cost of external funding. The motive for cash holding may also be precautionary. Companies often hold liquid reserves to cover unexpected shortages of funds as a consequence of frequent instability in financial markets 
(Stiglitz \& Weiss, 1984). However, despite the benefits they bring, cash holdings generate certain costs. Mostly, this includes the high opportunity costs of cash holding. Cash and cashequivalent reserves do not provide a return, or that return is minimal if it is in the form of highly liquid securities.

The most important theoretical concepts that explain a firm's managers motives to keep a certain level of cash holdings in the assets are trade-off theory, pecking order theory, and free cash flow theory. Trade-off theory starts with the premise that a company should seek an optimal level of cash holdings. This is the level that equates the marginal costs and marginal benefits of cash holding. On the other hand, pecking order theory prefers internal sources for the financing of current business activities. Financing from the net profit is the most effective source of financing. If the net profit is not sufficient, companies use accumulated funds. Borrowing on the financial market is the last option for financing current business activities (Myers,1984). Finally, free cash flow theory explains that managers tend to increase cash holdings under their control. They therefore tend to increase the ability to make investment decisions, which allows them to avoid external borrowing and market discipline. A higher degree of independence may result in the agency problem, because managers are given the opportunity to invest in projects that can be useful for them and harmful to shareholders.

On the basis of these theories, many characteristics of companies in previous research have been identified as determinants of cash holding. In this study, we aimed to assess the impact of certain empirical determinants on the level of cash holdings kept by companies in the Republic of Serbia. After the introductory part of the paper, in the second part we provide an overview of relevant research dealing with the analysis of the determinants of cash holdings. The third part provides a description of the sample used and the methodology. In the fourth part, the paper presents the results of the research, on the basis of which the fifth part presents the conclusions.

\section{LITERATURE REVIEW}

According to the consideration of the theories on corporate cash holdings, various companies' features such as growth (Haris \& Raviv, 1991; Shleifer \& Vishny, 1992), financial distress (Mackie-Mason, 1990; Ozkan \& Ozkan, 2004; Shah, 2011), cash flow volatility, size, dividend payments (Opler et al., 1999), leverage, profitability (Ferreira \& Vilela, 2004; Opler et al., 1999), debt maturity (Stohs \& Mauer, 1996), existence of a bank relationship, and cash cycle (Kalcheva \& Lins, 2007; Mauer \& Sherman, 1998) have been identified as determinants of cash holdings in previous studies.

Pecking order theory has been used to explain that companies prefer internal financing sources as opposed to external sources. This means that companies with higher cash flows have more cash holdings (Almeida, Campello \& Weishbach, 2004; Kalcheva \& Lins, 2007; Mauer \& Sherman, 1998). This is the same with volatile cash flows because such instability $i$ ncreases the probability of facing a lack of cash flow (Minton \& Schrand, 1999). Extra cash holdings thus provide a buffer when cashflows from operations unexpectedly fall. As a result, a positive relationship between cash holdings and cash flows is anticipated. The results of some research have indicated that there is a negative relationship between cash holdings and cash flows, which suggeststhat there are companies that consider cash flows an additional source of liquidity.

The next significant determinant of cash holdings is net working capital. Net working capital is an indicator of investments in liquid assets, and many companies consider this an additional source of liquidity. Therefore, a negative relationship between cash holdings and net working capital is expected (Almeida et al., 2004; Kalcheva \& Lins, 2007; Mauer \& Sherman, 1998). 
Another significant determinant of cash holdings is the turnover coefficient of working capital. The higher the turnover coefficient, the faster the turnover of a company's assets. This means that it is possible to finance the turnover with a smaller amount of working capital, which increases the efficiency of the company. Therefore, a negative relationship between cash holdings and the turnover coefficient of working capital is expected.

The size of a company is also a significant determinant of cash holdings. Small companies are more likely to be faced with information asymmetry and financial constraints. Therefore, they face higher transaction costs in accessing external financing sources, which increases the possibility of facing low cash levels (Brennan \& Hughes, 1991; Collins, Rozeff \& Dhaliwal, 1981; Mikkelson \& Partch, 2003; Pettit \& Singer, 1985). The literature has suggested that the chances of bankruptcy are higher for small companies, as they tend to be less diversified (Rajan \& Zingales, 1995; Titman \& Wessels, 1988). Miller and Orr (1966) suggested that large companies have economies of scale that allow them to manage their cash holdings efficiently. Also, Peterson and Rajan (2003) argued that external borrowing is less costly for large companies. All these arguments in turn imply that small companies should hold more cash. On the other hand, Opler et al. (1999) argued that large companies are more capable to accumulate cash because they may be more profitable in comparison with smaller companies. The alternative hypothesis is that cash holdings are in a positive correlation with the size of the company (Shah, 2011).

Numerous studies have indicated that financial leverage is a significant determinant of cash holdings. Companies may compensate for their lack of cash with funding from external sources. This implies that leveraging is in a negative correlation with the level of cash holdings. According to pecking order theory there is a negative correlation between cash holdings and financial leverage (Myers \& Majluf,
1984). However, the relationship is not linear. As the agency theory suggests, companies with high leverage raise additional funds in a more difficult way and hold more cash (Ogundipe, Salawu \& Ogundipe, 2012). It can be expected to have a positive relationship between leveraging and cash holdings.

Recent research on determinants of cash holding has analysed companies operating in developed countries (Almeida et al., 2004; Dittmar, 2004; Shah, 2011) as well as in developing countries (Dittmar \& Mahrt-Smith, 2007; Dittmar, MahrtSmith \& Servaes, 2003; Ferreira \& Vilela, 2004; Garcia-Terual \& Martinez-Solano, 2008; Guney, Ozkan \& Ozkan, 2007; Harford, Mansi \& Maxwell, 2008; Isshaq, Bokpin \& Onumah, 2009; Jensen, 1986). A research study conducted by Hall, Mateus and Mateus (2014), which also included a sample of companies from the Republic of Serbia, has analysed the differences in the levels of cash holdings between public and private companies, as well as differences in the levels of cash holdings between companies operating in developed markets and those operating in developing markets. This study has provided evidence on the determinants of cash holdings for companies from different sectors, expanding the knowledge about cash holdings among companies in the Republic of Serbia.

\section{DATA AND METHODOLOGY}

Our research was based on the use of panel data analysis. The analysis was performed on a sample of companies operating in the Republic of Serbia. The specific features of the sample and the methodology used are presented in the following section.

\section{Data}

The research was conducted on a sample of 2,352 non-financial companies from the Republic of Serbia, operating in 14 different 
sectors. In the period covered by the research, of liquidation, bankruptcy, or restructuring. none of the analysed companies was in the process

\begin{tabular}{|c|c|c|}
\hline Variable & Data description & Source \\
\hline Cash & $\begin{array}{l}\text { Cash and cash equivalents / } \\
\text { (Total assets - Cash and cash equivalents) }\end{array}$ & Balance sheet \\
\hline Size & Ln (Total assets) & Balance sheet \\
\hline Cf & $\begin{array}{l}\text { (Net profit before taxes + Depreciation and amortisation } \\
\text { expenses) / (Total assets- Cash and cash equivalents) }\end{array}$ & $\begin{array}{l}\text { Balance sheet, } \\
\text { Income statement }\end{array}$ \\
\hline Nwc & $\begin{array}{l}\text { (Current assets - Short-term liabilities - Cash and cash } \\
\text { equivalents) / (Total assets - Cash and cash equivalents) }\end{array}$ & Balance sheet \\
\hline Lvrg & $\begin{array}{l}\text { (Short-term debt }+ \text { Long-term debt) / } \\
\text { (Total assets - Cash and cash equivalents) }\end{array}$ & Balance sheet \\
\hline Turnover & Sales / Current assets & $\begin{array}{l}\text { Balance sheet, } \\
\text { Income statement }\end{array}$ \\
\hline
\end{tabular}

Table 1. Variable Descriptions.

Source: Specified databases.

Table 1 shows the balance sheet items included in the formula for calculating the variables used in the model. The sample included only companies that meet the following criteria: Cash $\leq 1,-1 \leq \mathrm{Cf} \leq$ $1, \operatorname{Nwc} \geq 5, \operatorname{Lvrg} \leq 5$, and Turnover $\leq 30$.

\section{Methodology}

According to an overview of relevant studies dealing with the assessment and analysis of empirical determinants of cash holdings in companies, the paper used the generalised method of moments (GMM) model (Arellano \& Bond, 1991). This model is particularly suited for the analysis of linear relationships in which the dependent variables are dynamic (dependent on the values from previous periods) and in which the independent variables are not strictly exogenous. Also, the application of dynamic panel models is considered to be effective in cases where the coefficients of the lagged variables are not of direct relevance for the model, because it allows the dynamics that can be crucial for a consistent evaluation of other parameters (Bond, 2002). Arellano \& Bond (1991) estimator is considered to be suitable for the analysis of panel datasets which are characterized with small values of $T$ (number of periods) and large values of $\mathrm{N}$ (number of observation units), which was a feature of the data set used in this study.

Dynamic relationships are characterised by the presence of a lagged dependent variable among the regressors:

$$
\begin{array}{r}
y_{i t}=\delta y_{i, t-1}+x_{i t}^{T} \beta+u_{i t} \\
i=1, K, N ; t=1 K, T
\end{array}
$$

where $\delta$ is a scalar, $x_{i t}$ is $1 \times \mathrm{K}$, and $\beta$ is $\mathrm{K} \times 1$. We will assume that the $u_{i t}$ follows a one-way error component model:

$u_{i t}=\mu_{i}+\varepsilon_{i t}$ 
where $\mu_{i} \sim \operatorname{IID}\left(0, \sigma^{2} \mu\right)$ and $\varepsilon_{i t} \sim \operatorname{IID}\left(0, \sigma^{2}{ }_{s}\right)$ are independent of each other.

The lag variable is included in order to capture the inertia of the dependent variable. There are two sources of this inertia: autocorrelation due to the presence of a lagged dependent variable among the regressors and individual effects characterising the heterogeneity among the individuals. However, given that $y_{i t}$ is a function of $\varepsilon_{i t}, y_{i, t-1}$ which is also a function of $\varepsilon_{i t}$, this means that $y_{i, t-1}$, which is included in the dynamic model as a regressor, is correlated with the error term (Baltagi, 1995). It is for this reason that traditional regression models were not suitable: the Ordinary Least Squares (OLS) estimator is biased and inconsistent, the within estimator is biased and inconsistent even for a relatively large $\mathrm{T}$, and the random effects estimator is biased. As a solution, Anderson \& Hsiao (1980) proposed first differencing the model (to eliminate the individual fixed effects) and then using higher-order lags as instrument variables (e.g., $\Delta y_{i, t-2}$ is an instrument for $\Delta y_{i, t-1}$ ), as these are expected to be orthogonal to the idiosyncratic error. Even though the method proposed by Anderson \& Hsiao (1980) leads to consistent estimates of the parameters, it is not necessarily efficient. A more efficient method proposed by Arellano \& Bond (1991) uses the same set of instruments but constructs moment conditions from them and uses the GMM to estimate the parameters. In this paper, we used a two-step GMM estimator:

$$
\begin{gathered}
\hat{\delta}=\left[\left(\Delta y_{-1}\right)^{T} W \hat{V}_{N}^{-1} W^{T}\left(\Delta y_{-1}\right)\right]^{-1} \\
{\left[\left(\Delta y_{-1}\right)^{T} W \widehat{V}_{N}^{-1} W^{T}(\Delta y)\right]}
\end{gathered}
$$

where $W$ is the matrix of instruments for $\Delta y_{-1}$ and a matrix $\widehat{V}_{N}^{-1}$ can be calculated from the residuals from the one-step Arellano and Bond (1991) estimation (see Baltagi (2011) for additional details). A consistent estimate of variance was calculated as follows:

$$
\widehat{\operatorname{var}}(\hat{\delta})=\left[\left(\Delta y_{-1}\right)^{T} W \widehat{V}_{N}^{-1} W^{T}\left(\Delta y_{-1}\right)\right]^{-1}
$$

In our case, the GMM model was specified as follows:

$$
\begin{aligned}
\operatorname{Cash}_{i t}= & \delta \operatorname{Cash}_{i(t-1)}+\beta_{1} \text { Size }_{i t}+\beta_{2} \operatorname{Cf}_{i t}+\beta_{3} N w c_{i t}+ \\
& +\beta_{4} \operatorname{Lvrg}_{i t}+\beta_{5} \text { Turnover }_{i t}+\mu_{i}+\varepsilon_{i t}
\end{aligned}
$$

The validity of the instruments chosen for the assessment of the dynamic panel model was tested by the Sargan test. Accepting the null hypothesis test that the selected instrumental variables were not correlated to the residuals indicated that the specification of the dynamic panel model was suie. In addition, two diagnostics were computed using the Arellano \& Bond (1991) GMM procedure to test for first-order and second-order serial correlation in the disturbances. If the model is properly specified, the null hypothesis (the absence of serial correlation) should be rejected in the first test, and should not be rejected in the second test (Baltagi, 2011).

\section{ESTIMATION RESULTS}

Table 2 shows the results of the estimated impact of the determinants of cash holdings at the level of the whole sample. The Sargan test did not reject the null hypothesis that the instrumental variables were uncorrelated with the residuals, indicating that the instrumental variables were valid. Moreover, the test for first-order and second-order serial correlation in the disturbances did not reject the absence of the second-order serial correlation, which means that the model was suitable. 


\begin{tabular}{|c|c|c|}
\hline Variable & GMM estimates & Diagnostic tests \\
\hline \multirow[t]{2}{*}{$\operatorname{lag}($ Cash, 1) } & $0.201^{\star * \star}$ & \\
\hline & $(0.086,0.316)$ & \\
\hline \multirow[t]{2}{*}{ Size } & -0.003 & Sargan test: Chisq $(9)=14.20898(\mathrm{p}$ value $=0.11508)$ \\
\hline & $(-0.012,0.007)$ & \\
\hline \multirow[t]{2}{*}{ Cf } & $0.110^{\star * *}$ & \\
\hline & $(0.083,0.138)$ & $\begin{array}{l}\text { Autocorrelation test }(1): \text { normal }=-6.917792(\mathrm{p} \text { value }= \\
\qquad 4.5874 \mathrm{e}-12)\end{array}$ \\
\hline \multirow[t]{2}{*}{ Nwc } & $-0.081^{* * *}$ & \\
\hline & $(-0.103,-0.058)$ & \\
\hline \multirow[t]{2}{*}{ Lvrg } & 0.013 & \\
\hline & $(-0.010,0.035)$ & $\begin{array}{l}\text { Autocorrelation test }(2): \text { normal }=1.609659(\mathrm{p} \text { value }= \\
0.10747)\end{array}$ \\
\hline \multirow[t]{2}{*}{ Turnover } & $-0.003^{\star * *}$ & \\
\hline & $(-0.005,-0.001)$ & \\
\hline Observations & $\mathrm{n}=2,352, \mathrm{t}=3-6, \mathrm{~N}=14,109$ & \\
\hline
\end{tabular}

Table 2. - Results of the dynamic linear panel model.

Source: Authors' calculations. Note: *, **, and *** indicate statistical significance at levels of 10\%, 5\%, and 1\%, respectively.

The estimated coefficients for the lagged dependent variable and cash flow were statistically significant and had a positive sign, whereas the regression coefficients for the net working capital and turnover variables were statistically significant and had a negative sign.

Table 3 shows the results of the estimated effect of the determinants of cash holding at the sector level of the sample for 14 sectors.

The impact of the determinants of cash holdings in the companies from the above-mentioned sectors did not essentially differ from their influence on the level of the total sample except in the case of the companies from several sectors where the size variable showed a statistically significant impact on cash holdings.

\section{CONCLUSIONS}

The obtained results led to the following conclusions regarding the cash holdings of non-financial companies in the Republic of Serbia. The effect of cash flows on cash holdings was positive and statistically significant. The positive value of $\mathrm{Cf}$ was compatible with the pecking order theory.

Therefore, this suggests that companies with higher cash flows prefer to hold more cash because they rely more on internal financing. Since the financial market of the Republic of Serbia is bank-centred, preferring internal sources of financing may be a consequence of banks' interest rates, which were at relatively high levels during the period covered by the research. The negative value of Nwc, which represents the 
liquidity variable, supported the hypothesis that companies with more liquid assets tend to reduce their cash levels. The obtained result is in accordance with the trade-off theory. The negative coefficient of the working capital turnover (the Turnover variable) suggests that companies with higher turnover of working capital have lower levels of cash holdings. The analysis of the results of the application of the model by sector may lead to identical conclusions, but in the case of several sectors, the coefficient of the size variable was negative and statistically significant. A reason for this is the fact that larger companies are more diversified, can get bank financing and access to capital markets far more easily, can minimise borrowing costs, and are less likely to go bankrupt.

According to the results, it can be generally concluded that companies operating in Serbia tend to have the optimal level of cash holdings and to prefer internal sources of financing in comparison with external sources, which is in line with the principles of trade-off theory and pecking order theory.

\section{REFERENCES}

Almeida, H., Campello, M., \& Weishbach, M. (2004). The cash flow sensitivity of cash. Journal of Finance, 59(4), 1777-1804.

Anderson, T. W., \& Hsiao, C. (1980). Estimation of dynamic models with error components. Retrieved from California Institute of Technology, Division of the Humanities and Social Sciences website: http:// econpapers.repec.org/RePEc:clt:sswopa:336

Arellano, M., \& Bond, S. (1991). Some tests of specification for panel data: Monte Carlo evidence and an application to employment equations. The Review of Economic Studies, 58(2), 277-297. http://doi. org/10.2307/2297968

Baltagi, B.H. (1995). Econometric analysis of panel data (3rd ed.). West Sussex, England: John Wiley \& Sons.

Baltagi, B. H. (2008). Econometric analysis of panel data (4th ed.).West Sussex, England: John Wiley \& Sons.

Baltagi, B. H. (2011). Econometrics. Berlin, Germany: Springer Berlin Heidelberg. http://doi. org/10.1007/978-3-642-20059-5
Bond, S. R. (2002). Dynamic panel data models: Aguide to micro data methods and practice. Portuguese Economic Journal, 1(2), 141-162. doi: 10.1007/ s10258-002-0009-9

Brennan, M. J., \& Hughes, P. J. (1991). Stock prices and the supply of information. The Journal of Finance, 46(5), 1665-1691.

Collins, D., Rozeff, M., \& Dhaliwal, D. (1981). The economic determinants of the market reaction to proposed mandatory accounting changes in the oil and gas industry. Journal of Accounting and Economics, 3(1), 37-71.

Dittmar, A. (2004). Capital structure in corporate spinoffs. Journal of Business, 77, 9-44.

Dittmar, A., \& Mahrt-Smith, J. (2007). Corporate governance and the value of cash holdings. Journal of Financial Economics, 83, 599-634.

Dittmar, A., Mahrt-Smith, J., \& Servaes, H. (2003). International corporate governance and corporate cash holdings. The Journal of Financial and Quantitative Analysis, 38(1), 111-133.

Ferreira, M. A., \& Vilela, A. (2004). Why do firms hold cash? Evidence from EMU countries. European Financial Management,10, 295-319.

Garcia-Terual, P. J., \& Martinez-Solano, P. (2008). On the determinants of SME cash holdings: Evidence from Spain. Journal of Business, Finance, and Accounting, 35(1/2), 127-149.

Guney, Y., Ozkan, A., \& Ozkan, N. (2007). International evidence on the nonlinear impact of leverage on corporate cash holdings. Journal of Multinational Financial Management, 17, 45-60.

Hall, T., Mateus, C., \& Mateus, I. B. (2014). What determines cash holdings at privately held and publicly traded firms? Evidence from 20 emerging markets. International Review of Financial Analysis, 33, 104-116.

Harford, J., Mansi, S., \& Maxwell, W. (2008). Corporate governance and firm cash holdings in the US. Journal of Financial Economics, 87, 535-555.

Haris, M., \& Raviv, A. (1991). The theory of capital structure. The Journal of Finance, 40, 297-355.

Isshaq, Z., Bokpin, G. A., \& Onumah, J. M. (2009). Corporate governance, ownership structure, cash holdings, and firm value on the Ghana Stock Exchange. The Journal of Risk Finance, 10(5), 488-499.

Jensen, M. C. (1986). Agency costs of free-cash-flow, corporate finance, and takeovers. American Economic Review, 76, 323-329. 
Kalcheva, A., \& Lins, K. V. (2007). International evidence of cash holdings and expected managerial agency problem. Review of Financial Studies, 20(4), 1087-1112.

Keynes, J. M. (1936). The general theory of employment, interest and money. London, England: Harcourt Brace.

Mackie-Mason, J. K. (1990). Do taxes affect corporate financing decisions? The Journal of Finance,45(4), 1471-1493.

Mauer, K. D., \& Sherman, A. (1998). The determinants of corporate liquidity: Theory and evidence. The Journal of Financial and Quantitative Analysis, 33, 335-359.

Mikkelson, W. H., \& Partch, M. M. (2003). Do persistent large cash reserves hinder performance? Journal of Financial and Quantitative Analysis, 38, 275-294.

Miller, M. H., \& Orr, D. (1966). A model of demand for money by firms. Quarterly Journal of Economics, 80(3), 413-435.

Minton, B. A., \& Schrand, C. (1999). The impact of cash flow volatility on discretionary investment and the costs of debt and equity financing. Journal of Financial Economics, 54(3), 423-460.

Myers, S. C. (1984). The capital structure puzzle. Journal of Finance, 39, 575-592.

Myers, S., \& Majluf, N. (1984). Corporate financing and investment decisions when firms have information that investors do not have. Journal of Financial Economics, 13, 187-221.

Ogundipe, S. E., Salawu, R. O., \& Ogundipe, L. O. (2012). The determinants of corporate cash holdingsin Nigeria: Evidence from general method of moments (GMM). International Journal of Social, Behavioral, Educational, Economic and Management Engineering, 6(1), 24-30.

Opler,T. L., Pinkowitz, R. S., \& Williamson, R. (1999). The determinants and implications of corporate cash holdings. Journal of Financial Economics, 52(1), 3-46.

Ozkan, A., \& Ozkan, N. (2004). Corporate cash holdings: An empirical investigation of UK companies, Journal of Banking and Finance, 28, 2103-2134.

Peterson, M., \& Rajan, R. (2003). Does distance still matter? The information revolution in small busness lending. Journal of Finance, 57, 2533-2570
Pettit, R. R., \& Singer, R. F. (1985). Small business finance: A research agenda. Financial Management, 14(3), 47-60.

Rajan, R. G., \& Zingales, L. (1995). What do we know about capital structure? Some evidence from international data. The Journal of Finance, 50(5), 1421-1460.

Shah, A. (2011). The corporate cash holding: Determinants and implications. African Journal of Business Management, 34(5), 12939-12950.

Shleifer, A., \& Vishny, A. (1992). Liquidation values and debt capacity: A market equilibrium approach. The Journal of Finance, 47(4), 1343-1366.

Stiglitz, J., \& Weiss, A. (1984). Information imperfections in the capital market and macroeconomic fluctuations. American Economic Review, 74, 194-199.

Stohs, M. H., \& Mauer, D. C. (1996). The determinants of corporate debt maturity structure. The Journal of Business, 69(3), 279-312.

Titman, S., \& Wessels, R. (1988). The determinants of capital structure choice. The Journal of Finance, 43(1), 1-19. 


\begin{tabular}{|c|c|c|c|c|c|c|c|c|}
\hline 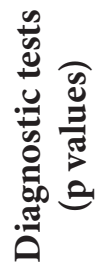 & 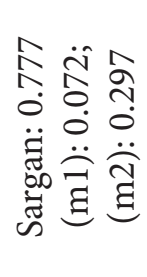 & 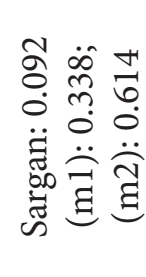 & 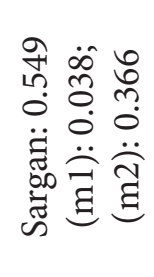 & 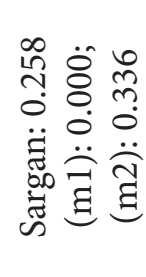 & 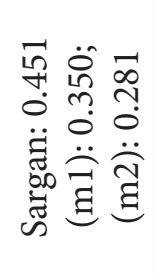 & 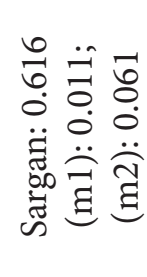 & 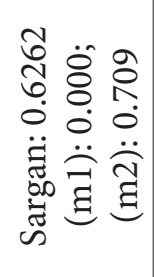 & 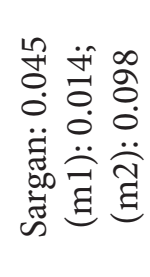 \\
\hline 苛 & $\begin{array}{rl} & \widehat{0} \\
0 & 8 \\
0 & 0 \\
8 & 0 \\
0 & 1 \\
0 & 0 \\
1 & 0 \\
0 & 1\end{array}$ & 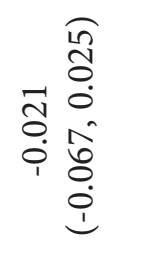 & 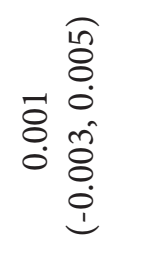 & 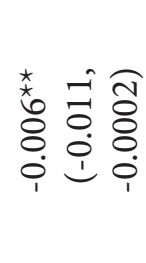 & 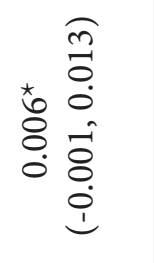 & 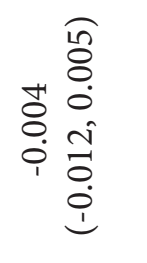 & 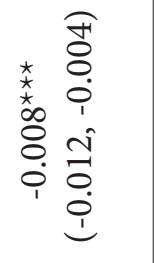 & 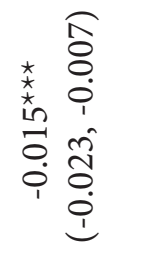 \\
\hline 染 & $\begin{array}{c}0 \\
0 \\
0 \\
0 \\
0 \\
0 \\
0 \\
0 \\
0 \\
0 \\
0 \\
0 \\
0 \\
0 \\
1\end{array}$ & 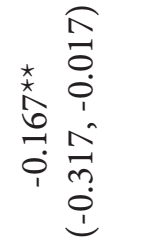 & $\begin{aligned} & 0 \\
& 0 \\
& 0 \\
& \infty \\
& 0 \\
& 0 \\
& 0 \\
& 0 \\
& 0 \\
& 0 \\
& 0 \\
& 0 \\
& 0 \\
& 0 \\
& i\end{aligned}$ & $\begin{array}{ll} & 0 \\
& 8 \\
\star & 0 \\
0 & 0 \\
0 & 0 \\
0 & 0 \\
0 & 0 \\
1 & 0 \\
1\end{array}$ & 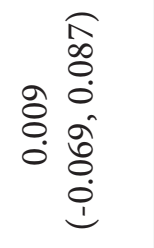 & $\begin{array}{ll} & \widehat{0} \\
& 0 \\
0 \\
0 \\
0 \\
0 \\
0 \\
0 \\
0 \\
0 \\
0 \\
0 \\
0\end{array}$ & 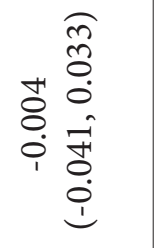 & 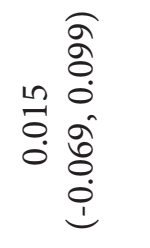 \\
\hline 岂 & 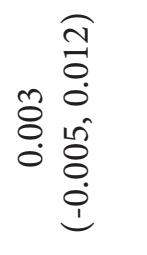 & 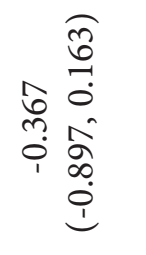 & 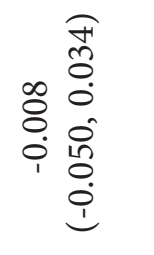 & 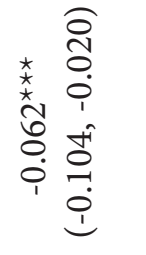 & 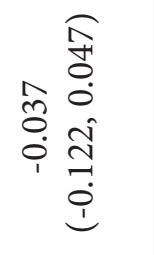 & 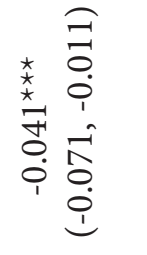 & 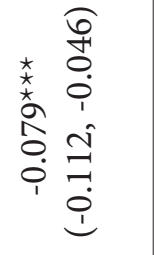 & 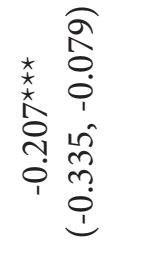 \\
\hline$\tilde{U}$ & 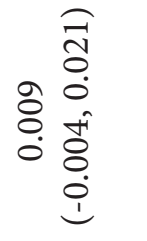 & 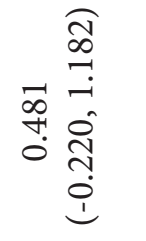 & $\begin{array}{ll} & \widehat{a} \\
0 & 0 \\
0 & 0 \\
0 & 0 \\
0 & \infty \\
0 & 0 \\
0 & 0 \\
0 & 1\end{array}$ & 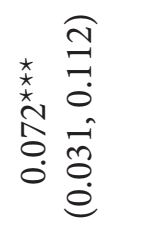 & 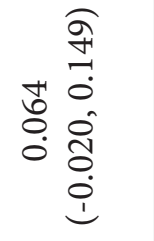 & 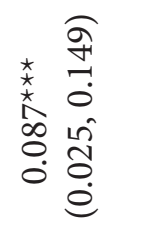 & 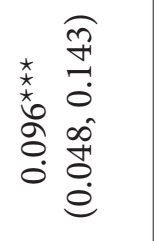 & 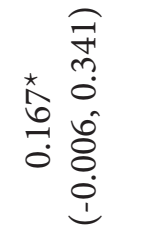 \\
\hline है & 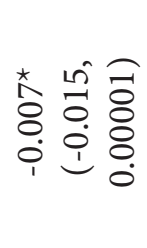 & 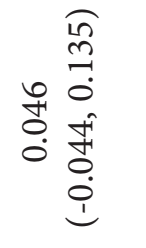 & 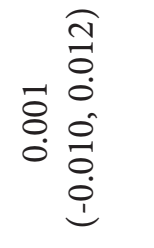 & 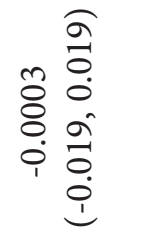 & 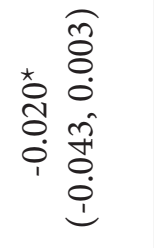 & 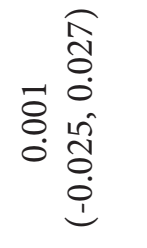 & 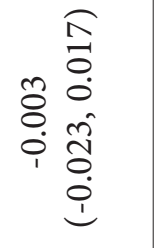 & 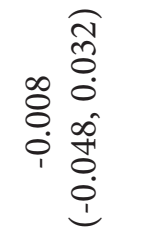 \\
\hline 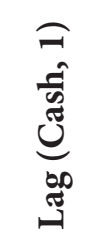 & 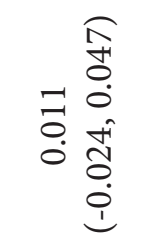 & 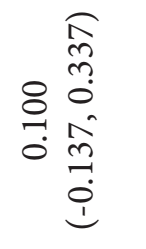 & 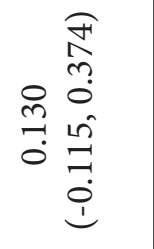 & 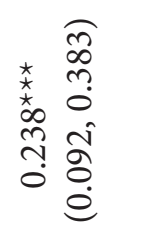 & 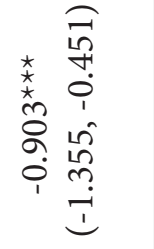 & 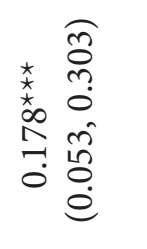 & 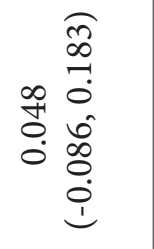 & 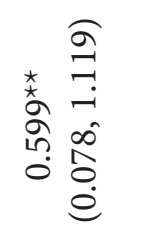 \\
\hline & 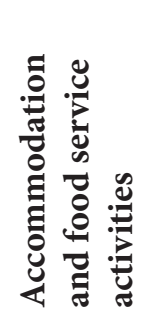 & 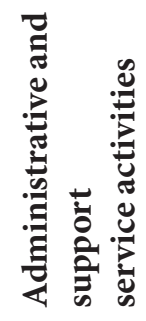 & 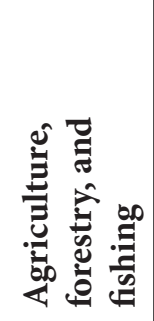 & 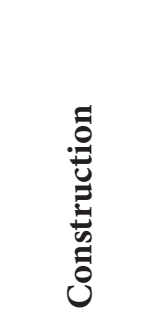 & 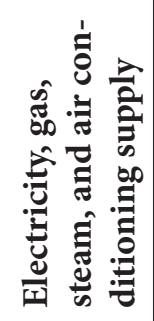 & 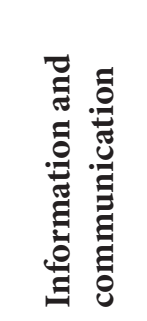 & 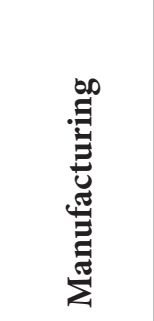 & 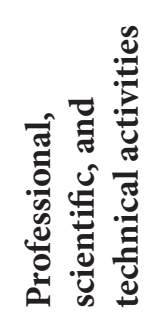 \\
\hline
\end{tabular}




\begin{tabular}{|c|c|c|c|c|c|}
\hline 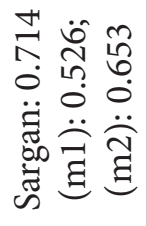 & 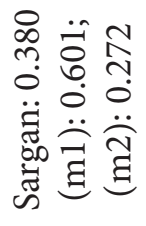 & 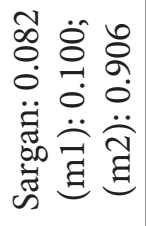 & 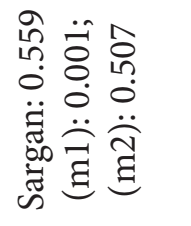 & 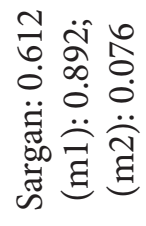 & 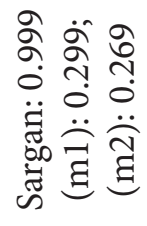 \\
\hline 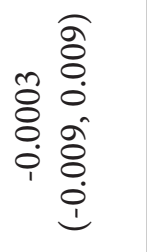 & 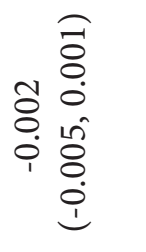 & 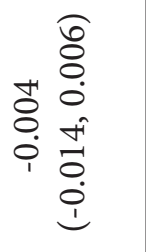 & 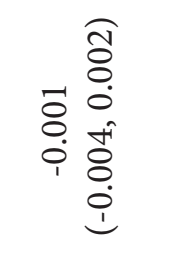 & 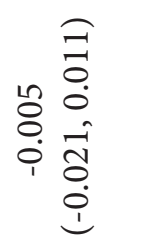 & 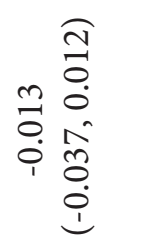 \\
\hline 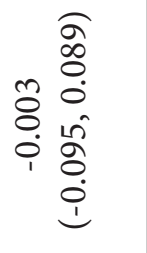 & 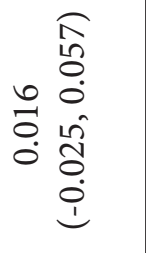 & 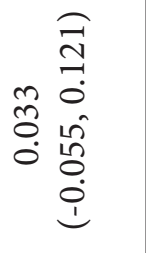 & 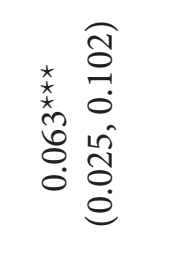 & 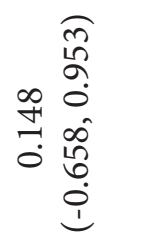 & 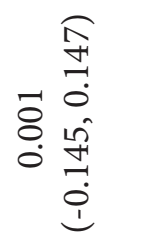 \\
\hline $\begin{aligned} & 0 \\
& 0 \\
& 0 \\
& 0 \\
& 0 \\
& 0 \\
& 0 \\
& 0 \\
& 0 \\
& 0 \\
& 0 \\
& 0 \\
& 0 \\
& i\end{aligned}$ & 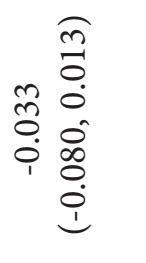 & 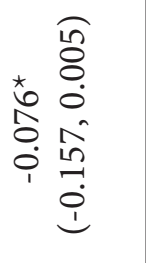 & 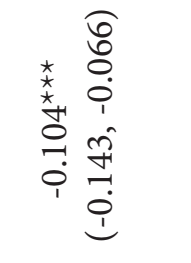 & 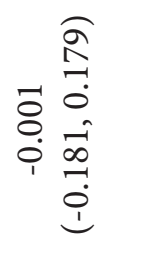 & 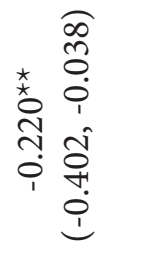 \\
\hline 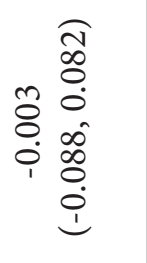 & 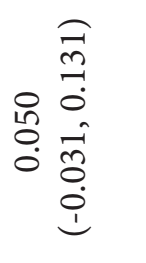 & 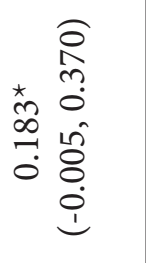 & 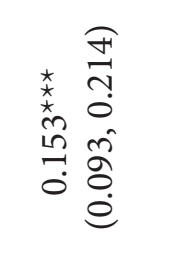 & 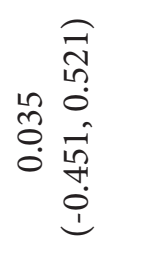 & 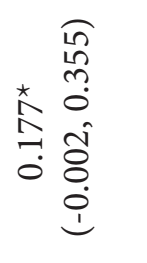 \\
\hline 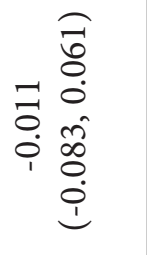 & 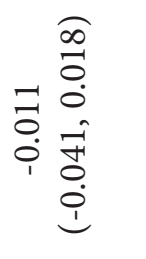 & 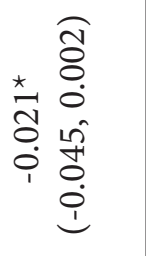 & 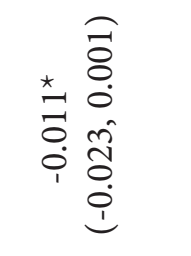 & 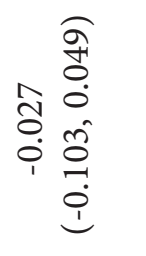 & 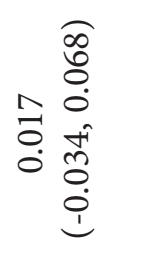 \\
\hline 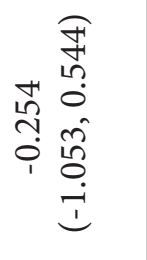 & $\begin{aligned} & 0 \\
& 8 \\
& 0 \\
& m \\
& 0 \\
& 0 \\
& 0 \\
& 0 \\
& 0 \\
& 1 \\
& 0 \\
& 0 \\
& 0 \\
& 1\end{aligned}$ & 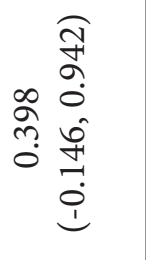 & 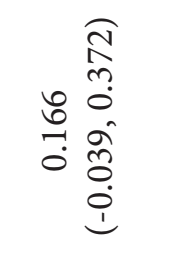 & 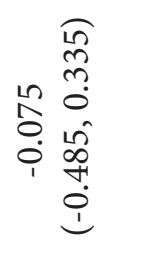 & 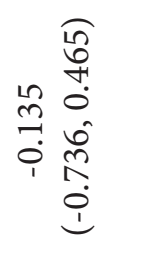 \\
\hline 总 & 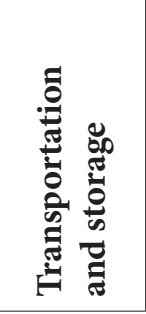 & 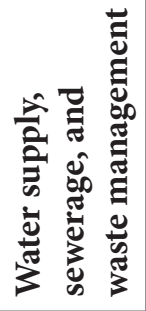 & 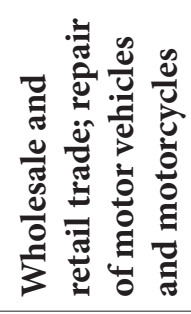 & 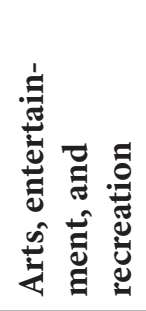 & 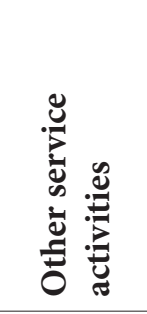 \\
\hline
\end{tabular}




\section{ANALIZA DETERMINANTI KORPORATIVNIH GOTOVINSKIH POZICIJA - PRIMERI IZ REPUBLIKE SRBIJE}

\section{Rezime:}

Cilj ovog istraživanja je analiza empirijskih determinanti vrednosti gotovinskih pozicija na uzorku industrijskih privrednih društava koja posluju u Republici Srbiji. U tu svrhu, korišćenjem generalizovane metode momenata, specificiran je dinamički panel model za period posmatranja od 2008. do 2013. godine. Rezultati analize ukazuju da društva koja imaju veće novčane tokove imaju veće vrednosti gotovinskih pozicija. Veća društva, kao i ona koja imaju više likvidnih sredstava u svojoj imovini, imaju tendenciju smanjenja vrednosti gotovinskih pozicija. Društva koja posluju u Republici Srbiji drže optimalne vrednosti gotovine i preferiraju interne izvore finansiranja, što je u skladu sa principima „trade-off” i „pecking order” teorija upravljanja gotovinskim pozicijama.

\section{Ključne reči:}

likvidnost,

izvori finansiranja,

korporativne gotovinske pozicije,

Republika Srbija,

dinamički panel model. 